\title{
GROWTH AND YIELD OF CHICKPEA AS AFFECTED BY DE- TOPPING TIME AND HEIGHT
}

\author{
M.S. Kobir*, M.O. Ali, M.J. Hossain, M.S. Alam, S. Paul, P. Hajong and M. H. Rahman \\ Bangladesh Agricultural Research Institute, Bangladesh \\ *Corresponding Email: Shahriar1302027@gmail.com
}

(Received: 04 October 2021, Accepted: 09 December 2021)

Keyword: De-topping, nipping, chickpea, time, height, yield

\begin{abstract}
The production area of chickpea in Bangladesh is decreasing day by day due to the competition with higher yielding crop which is/or profitable than chickpea. As such, the experiment was undertaken at Regional Agricultural Research Station, Jashore during 2019-2020 and 2020-2021 to study the effect of most suitable method of de-topping (nipping) in chickpea (var. BARI Chola-10) for its growth and yield improvement. Treatments were imposed in a split-plot design where in main plot : time of nipping : 30 days after emergence (DAE), 40 DAE $E_{3}-50$ DAE and in sub-plot: different heights of nipping practices: Control, Nipping $5 \mathrm{~cm}$ from growing tip, Nipping $8 \mathrm{~cm}$ from growing tip and Nipping $10 \mathrm{~cm}$ from growing tip. In interaction treatment, the highest days to flower (68), days to mature (112), vegetable yield $\left(703 \mathrm{~kg} \mathrm{ha}^{-1}\right)$ was observed when chickpea plants were de-topped after 50 DAE at $10 \mathrm{~cm}$ from growing tip. The highest plant height $(46 \mathrm{~cm})$ was observed when de-topping at $40 \mathrm{DAE}$ was done at $10 \mathrm{~cm}$ from growing tip. Seed yield (1419.95 $\mathrm{kg} \mathrm{ha}^{-1}$ ) and Marginal Benefit Cost Ratio (MBCR) (13.1) was recorded maximum when chickpea plants de-topped $50 \mathrm{DAE}$ at $5 \mathrm{~cm}$ from growing tip. De-topping practices in chickpea (var. BARI Chola-10) after 50 DAE at 5 $\mathrm{cm}$ from growing tip could maximize the productivity of chickpea.
\end{abstract}

\section{Introduction}

Per capita availability of pulses is very low against per capita demand due to back drop of pulses production (Azad et al., 2019). Among the pulse crops chickpea is one of the most important pulses crop in Bangladesh as it contains protein (\%) in almost half of its' individual seed weight. Bangladesh has to import a huge amount of chickpea each year due to its huge shortage against demand of production. Removal of apical meristem (apical dominance of auxin) is termed as de-topping / nipping (Khan et al., 1993) which promotes the emergence lateral branches due to role of cytokinins (Campbell et al., 2008). The more the lateral branches the more the flower initiating points that increases yield. Number of branches followed by more pods are the resulted effect of de-topping at various stages of plant growth that boost the grain yield of chickpea (Aziz, 2000; Aslam et al., 2008). Severity of diseases are reduced and yield is increased in case of de-topping at 45 days after sowing (Sumarjit and Sophia, 2006). In addition, de-topped chickpea leaves are a good source of fodder (Zahid et al., 1997). So, this experiment was undertaken to study the effect of de-topping practice along with its time and find out suitable de-topping management in chickpea (var. BARI Chola-10) for yield improvement.

\section{Materials and Methods}

The experiment was conducted in the Regional Agricultural Research station, Bangladesh Agricultural Research Institute, Jashore during Rabi season of 2019-20 and 2020-21. The latitude, longitude and altitude of this site is $23^{\circ} 18^{\prime} \mathrm{N}, 8^{0} 18^{\prime} \mathrm{E}$ and $19 \mathrm{~m}$, respectively (Kobir et al., 2020). The site belongs to AEZ-11 n 'High Ganges River Floodplain' (BBS, 2019). The soil of the experimental field was sandy clay-loam in texture with medium high land. Treatments were imposed in a split-plot design where in main plot : Time of de-topping/ nipping (03): i) $E_{1}-30$ days after emergence (DAE) ii) $E_{2}-40$ 
DAE iii) $E_{3-} 50$ DAE an in sub-plot different heights of nipping practices (04): $\mathrm{T}_{1}-$ Control, $\mathrm{T}_{2}$ Nipping $5 \mathrm{~cm}$ from growing tip, $\mathrm{T}_{3}$ - Nipping $8 \mathrm{~cm}$ from growing tip, $\mathrm{T}_{4}-\mathrm{Nipping} 10 \mathrm{~cm}$ from growing tip. . The chickpea var. BARI Chola-10 was used. Fertilizers were given as basal as $\mathrm{N}_{2} \mathrm{P}_{2} \mathrm{O}_{5}, \mathrm{~K}_{2} \mathrm{O}, \mathrm{S}$ and B @ 20,40,20, 20,1 $\mathrm{kg} \mathrm{ha}^{-1}$, respectively. Different parameters on growth, yield components and yield of chickpea were studied. Data were tabulated by Microsoft excel software and data were analyzed by statistical software "R" packages.

\section{Results and Discussion}

Results revealed that treatment nipping had significant influence on plants $\mathrm{m}^{-2}$, days to flower, days to maturity, plant height, pods plant ${ }^{-1}$, vegetable production $\mathrm{ha}^{-1}$ and seed yield ha- ${ }^{-1}$ (Table 1). Nipping at 40 DAE showed maximum $t$ values of days to maturity, pods plant ${ }^{-1}$, branches plant ${ }^{-1}$, seed yield and followed by nipping at $50 \mathrm{DAE}$ but only vegetable yield was highest with later nipping and followed by 10 days earlier this practice. Nipping $30 \mathrm{DAE}$ was proved comparatively lower in each parameter.

Table 1. Growth and yield of chickpea as affected by nipping (Pooled over the years)

\begin{tabular}{lcccccccc}
\hline Treatments & $\begin{array}{c}\text { Plants } \\
\mathbf{m}^{-2} \\
(\mathbf{n o .})\end{array}$ & $\begin{array}{c}\text { Days to } \\
\text { flowering } \\
(\text { (no.) }\end{array}$ & $\begin{array}{c}\text { Days to } \\
\text { maturity } \\
(\mathbf{n o} .)\end{array}$ & $\begin{array}{c}\text { Plant } \\
\text { height } \\
(\mathbf{c m})\end{array}$ & $\begin{array}{c}\text { Pods } \\
\text { plant }^{-1} \\
(\mathbf{n o})\end{array}$ & $\begin{array}{c}\text { Branches } \\
\text { plant }^{-1} \\
(\text { (no. })^{-1}\end{array}$ & $\begin{array}{c}\text { Vegetable } \\
\text { production }_{\left(\mathbf{k g ~ h a}^{-1}\right)}\end{array}$ & $\begin{array}{c}\text { Seed } \\
\text { yield } \\
\left(\mathbf{k g ~ h a}^{-1}\right)\end{array}$ \\
\hline $\mathrm{E}_{1}$ & 22 & 62 & 114 & 42 & 21 & 2 & 123 & 663 \\
$\mathrm{E}_{2}$ & 32 & 64 & 116 & 44 & 28 & 3 & 212 & 1201 \\
$\mathrm{E}_{3}$ & 38 & 65 & 115 & 39 & 26 & 3 & 385 & 1150 \\
\hline $\mathrm{CV}(\%)$ & 6.98 & 1.25 & 0.75 & 11.45 & 17.35 & 12.20 & 19.68 & 18.00 \\
\hline $\mathrm{LSD}_{(0.05)}$ & 2.13 & 0.77 & 0.91 & 2.97 & 3.89 & $\mathrm{NS}$ & 55.63 & 242.68 \\
\hline
\end{tabular}

$\mathrm{E}_{1}-30$ days after emergence, $\mathrm{E}_{2}-40$ days after emergence, $\mathrm{E}_{3}-50$ days after emergence

Plants $\mathrm{m}^{-2}$, days to flower, vegetable production $\mathrm{ha}^{-1}$ and seed yield $\mathrm{ha}^{-1}$ were significantly varied due to nipping point when days to maturity, plant height, pods plant ${ }^{-1}$, branches plant ${ }^{-1}$ did not response with the practice (Table 2 ).

Table 2. Growth and yield of chickpea as affected by different height of nipping (Pooled over the years)

\begin{tabular}{lcccccccc}
\hline Treatments & $\begin{array}{c}\text { Plantsm } \\
-2 \\
\text { (no.) }\end{array}$ & $\begin{array}{c}\text { Days to } \\
\text { flowering } \\
\text { (no.) }\end{array}$ & $\begin{array}{c}\text { Days to } \\
\text { maturity } \\
\text { (no.) }\end{array}$ & $\begin{array}{c}\text { Plant } \\
\text { height } \\
\text { (cm) }\end{array}$ & $\begin{array}{c}\text { Pods } \\
\text { plant } \\
\text { (no.) }\end{array}$ & $\begin{array}{c}\text { Branches } \\
\text { plant }^{-1} \\
(\text { (no.) }\end{array}$ & $\begin{array}{c}\text { Vegetable } \\
\text { production } \\
\left(\mathrm{kg} \mathrm{ha}^{-1}\right)\end{array}$ & $\begin{array}{c}\text { Seed } \\
\text { Yield } \\
\left(\mathrm{kg} \mathrm{ha}^{-1}\right)\end{array}$ \\
\hline $\mathrm{T}_{1}$ & 31 & 63 & 115 & 43 & 25 & 3 & 0 & 894 \\
$\mathrm{~T}_{2}$ & 30 & 64 & 115 & 41 & 28 & 3 & 223 & 1150 \\
$\mathrm{~T}_{3}$ & 30 & 64 & 115 & 43 & 25 & 3 & 283 & 1068 \\
$\mathrm{~T}_{4}$ & 33 & 65 & 115 & 41 & 22 & 3 & 455 & 974 \\
\hline $\mathrm{CV}(\%)$ & 6.96 & 1.37 & 0.61 & 7.46 & 26.91 & 15.39 & 14.54 & 14.10 \\
\hline $\mathrm{LSD}_{(0.05)}$ & 2.1 & 0.84 & $\mathrm{NS}$ & $\mathrm{NS}$ & $\mathrm{NS}$ & $\mathrm{NS}$ & 57.59 & 232.00 \\
\hline
\end{tabular}

$\mathrm{T}_{1}$ - Control, $\mathrm{T}_{2}$ - Nipping $5 \mathrm{~cm}$ from growing tip, $\mathrm{T}_{3}$ - Nipping $8 \mathrm{~cm}$ from growing tip, $\mathrm{T}_{4}$ - Nipping $10 \mathrm{~cm}$ from growing tip Nipping $10 \mathrm{~cm}$ growing tip gave maximum plants $\mathrm{m}^{-2}$, days to flower, vegetable production $\mathrm{ha}^{-1}$ and at par with other nipping times but vegetable yield was obtained highest with de-topped $10 \mathrm{~cm}$ tip. Numerically greater number of pods plant ${ }^{-1}$ was registered with nipping $5 \mathrm{~cm}$ growing tip, that treatment increased seed yield maximum and followed by 8 and $10 \mathrm{~cm}$ nipping. Treatment no nipping (control) had no additional vegetable yield and poor seed yield thus knocking at nipping practices.

In case of combined effect, the highest plant height was found when chickpea plants de-topped after 40 days of emergence at $10 \mathrm{~cm}$ from growing tip and the lowest plant height was found when chickpea plants were de-topped after 50 days of emergence at both $10 \mathrm{~cm}$ and $5 \mathrm{~cm}$ from growing tip. When chickpea plants were de-topped in 40 days after emergence at $10 \mathrm{~cm}$ from growing tip, the plants get 
adequate days to attain highest apical height which is not possible when chickpea were de-topped in 50 days after emergence. Aslam et al. (2008) however pointed out that vigorous cutting of chickpea plants is related to tallest plant. The highest plants $\mathrm{m}^{-2}$, days to flower and days to mature was recorded when chickpea plants de-topped $50 \mathrm{DAE}$ at $10 \mathrm{~cm}$ from growing tip. On the other hand, the lowest plants $\mathrm{m}^{-2}$, days to flower and days to mature was observed when chickpea plants de-topped after $30 \mathrm{DAE}$ at $5 \mathrm{~cm}$ from growing tip, not de-topped at $30 \mathrm{DAE}$, respectively (Table 3). Gaudreau et al. (2020) claimed that de-topping in later stage of vegetative growth, the auxiliary inflorescence can only initiate after the recovery period which can delay the overall growth of the plant thus maturity gets later. But de-topping in early stage of vegetative growth, the plants can get adequate days to flower after recovering from pruning. The highest branches plant ${ }^{-1}$ was found when chickpea plants were not de-topped at 40 days after emergence and the lowest branches plant ${ }^{-1}$ was found when chickpea plants were de-topped after 30 days of emergence at $10 \mathrm{~cm}$ from growing tip. The highest pods plant $^{-1}$ was found when chickpea plants de-topped after both 40 and 50 days of emergence at $5 \mathrm{~cm}$ from growing tip and the lowest pods plant $^{-1}$ was found when chickpea plants were de-topped after 30 days of emergence at $10 \mathrm{~cm}$ from growing tip (Table 3).

Table 3. Combined effect of nipping time and height on phenology of chickpea (Pooled basis of two year)

\begin{tabular}{lcccccc}
\hline $\begin{array}{c}\text { Combined } \\
\text { treatment }\end{array}$ & $\begin{array}{c}\text { Plants } \\
\mathbf{m}^{-2} \\
(\mathbf{n o})\end{array}$ & $\begin{array}{c}\text { Days to } \\
\text { flowering } \\
\text { (no.) }\end{array}$ & $\begin{array}{c}\text { Days to } \\
\text { maturity } \\
\text { (no.) }\end{array}$ & $\begin{array}{c}\text { Plant height } \\
(\mathbf{c m})\end{array}$ & $\begin{array}{c}\text { Pods plant } \\
(\text { no. })\end{array}$ & $\begin{array}{c}\text { Branches }_{\text {plant }^{-1}} \\
(\mathbf{n o .})\end{array}$ \\
\hline $\mathrm{E}_{1} \mathrm{~T}_{1}$ & 28 & 57 & 112 & 41.5 & 23 & 3 \\
$\mathrm{E}_{1} \mathrm{~T}_{2}$ & 16 & 62 & 114 & 41.5 & 21 & 3 \\
$\mathrm{E}_{1} \mathrm{~T}_{3}$ & 18 & 62 & 114 & 42.5 & 21 & 2 \\
$\mathrm{E}_{1} \mathrm{~T}_{4}$ & 23 & 64 & 115 & 40 & 15 & 2 \\
$\mathrm{E}_{2} \mathrm{~T}_{1}$ & 28 & 60 & 114 & 45 & 26 & 3 \\
$\mathrm{E}_{2} \mathrm{~T}_{2}$ & 31 & 63 & 115 & 42 & 30 & 3 \\
$\mathrm{E}_{2} \mathrm{~T}_{3}$ & 33 & 65 & 116 & 45.5 & 26 & 3 \\
$\mathrm{E}_{2} \mathrm{~T}_{4}$ & 34 & 65 & 117 & 44.5 & 28 & 3 \\
$\mathrm{E}_{3} \mathrm{~T}_{1}$ & 35 & 60 & 113 & 41 & 24 & 3 \\
$\mathrm{E}_{3} \mathrm{~T}_{2}$ & 38 & 64 & 114 & 38 & 30 & 3 \\
$\mathrm{E}_{3} \mathrm{~T}_{3}$ & 38 & 65 & 116 & 39 & 27 & 3 \\
$\mathrm{E}_{3} \mathrm{~T}_{4}$ & 41 & 67 & 118 & 38 & 21 & 3 \\
\hline $\mathrm{CV}_{2}(\%)$ & 6.96 & 1.37 & 0.61 & 7.46 & 17.91 & 15.39 \\
\hline $\mathrm{LSS}_{(0.05)}$ & 3.79 & 1.48 & 1.68 & 5.95 & 10.66 & 0.70 \\
\hline
\end{tabular}

$\mathrm{E}_{1}-30$ days after emergence, $\mathrm{E}_{2}-40$ days after emergence, $\mathrm{E}_{3}-50$ days after emergence,

$\mathrm{T}_{1}$ - Control, $\mathrm{T}_{2}$ - Nipping $5 \mathrm{~cm}$ from growing tip, $\mathrm{T}_{3}$ - Nipping $8 \mathrm{~cm}$ from growing tip, $\mathrm{T}_{4}-\mathrm{Nipping} 10 \mathrm{~cm}$ from growing tip In the pooled basis of analysis, the highest vegetable yield was found from de-topping after 50 days of emergence at $10 \mathrm{~cm}$ from growing tip and the lowest vegetable yield was found when chickpea crops not de-topped in 30, 40 and 50 days after emergence (Figure 1). The highest seed yield was found from de-topping after 50 days of emergence at $5 \mathrm{~cm}$ from growing tip and the lowest seed yield was found when chickpea crops were not de-topped in 30 days after emergence (Figure 1). This may be happened due to light nipping at certain period of time can enhance plant height, branches plant ${ }^{-1}$, pods plant $^{-1}$, days to flower as well as days to mature, those lead to increase in seed yield. Aslam et al. (2010) reported that removal of $2 \mathrm{~cm}$ from growing tip at 70 days after sowing gave the highest seed yield and the lowest seed yield was found in control. Similar trend also found by Even and Wahab (1983) and Othman and Wan (1987). 


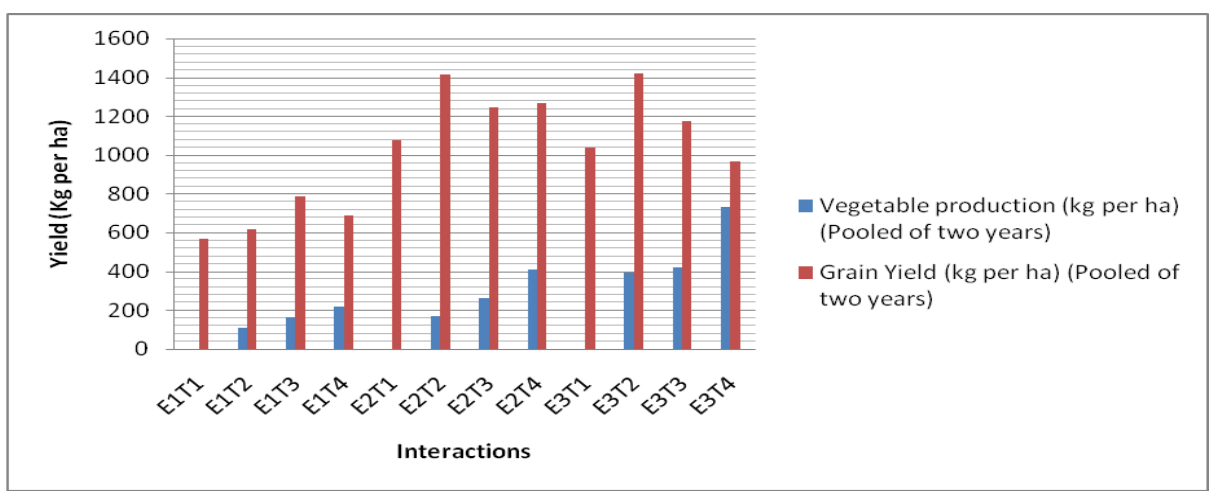

$\mathrm{E}_{1}-30$ days after emergence, $\mathrm{E}_{2}-40$ days after emergence, $\mathrm{E}_{3}-50$ days after emergence,

$\mathrm{T}_{1}$ - Control, $\mathrm{T}_{2}$ - Nipping $5 \mathrm{~cm}$ from growing tip, $\mathrm{T}_{3}$ - Nipping $8 \mathrm{~cm}$ from growing tip, $\mathrm{T}_{4}$ - Nipping $10 \mathrm{~cm}$ from growing tip

Fig.1. Combined effect of nipping time and height on vegetable and grain yield of chickpea.

Cost analysis: Partial cost analysis of chickpea de-topping showed that the highest total additional taka over control and marginal benefit cost ratio achieved when chickpea crops was de-topped in 50 DAE at $5 \mathrm{~cm}$ from growing tip $\left(\mathrm{E}_{3} \mathrm{~T}_{2}\right)$. The lowest total additional taka over control and marginal benefit cost ratio calculated when chickpea crops were de-topped in 30 days after emergence at $5 \mathrm{~cm}$ from growing tip $\left(\mathrm{E}_{1} \mathrm{~T}_{2}\right)($ Table 4$)$.

Table 4. Partial cost analysis of different treatment combinations (2019-20 and 2020-21)

\begin{tabular}{cccccccccc}
\hline Combined & \multicolumn{1}{c}{ Total Add. TK. over control } & \multicolumn{3}{c}{ Cost of treatment } & \multicolumn{3}{c}{ MBCR } \\
\cline { 2 - 11 } Treatment & $\mathbf{2 0 1 9 - 2 0}$ & $\mathbf{2 0 2 0 - 2 1}$ & Mean & $\mathbf{2 0 1 9 - 2 0}$ & $\mathbf{2 0 2 0 - 2 1}$ & mean & $\mathbf{2 0 1 9 - 2 0}$ & $\mathbf{2 0 2 0 - 2 1}$ & Mean \\
\hline $\mathrm{E}_{1} \mathrm{~T}_{1}$ & - & - & - & - & - & & - & - & - \\
$\mathrm{E}_{1} \mathrm{~T}_{2}$ & 9988.8 & 8420 & 9204.4 & 3600 & 3600 & 3600 & 2.7 & 2 & 2.3 \\
$\mathrm{E}_{1} \mathrm{~T}_{3}$ & 25216.0 & 23580 & 24398 & 4800 & 4800 & 4800 & 5.2 & 5 & 5.1 \\
$\mathrm{E}_{1} \mathrm{~T}_{4}$ & 21195.3 & 19550 & 20372.6 & 7000 & 7000 & 7000 & 3.0 & 3 & 3.0 \\
$\mathrm{E}_{2} \mathrm{~T}_{1}$ & - & - & - & - & - & - & - & - & - \\
$\mathrm{E}_{2} \mathrm{~T}_{2}$ & 34041.6 & 32450 & 33245.8 & 3600 & 3600 & 3600 & 9.4 & 9 & 9.2 \\
$\mathrm{E}_{2} \mathrm{~T}_{3}$ & 34041.6 & 25595 & 29818.3 & 4800 & 4800 & 4800 & 7.0 & 7 & 7.0 \\
$\mathrm{E}_{2} \mathrm{~T}_{4}$ & 37147.4 & 35180 & 36163.7 & 7000 & 7000 & 7000 & 5.0 & 5 & 5.1 \\
$\mathrm{E}_{3} \mathrm{~T}_{1}$ & - & - & - & - & - & - & - & - & - \\
$\mathrm{E}_{3} \mathrm{~T}_{2}$ & 51612.2 & 44755 & 48183.6 & 3600 & 3600 & 3600 & 14.3 & 12 & 13.1 \\
$\mathrm{E}_{3} \mathrm{~T}_{3}$ & 34151.5 & 30900 & 32525.7 & 4800 & 4800 & 4800 & 7.1 & 6 & 6.5 \\
$\mathrm{E}_{3} \mathrm{~T}_{4}$ & 41966.6 & 38665 & 40315.8 & 7000 & 7000 & 7000 & 5.9 & 6 & 5.9 \\
\hline
\end{tabular}

E1-30 days after emergence, $E_{2}-40$ days after emergence, $E_{3}-50$ days after emergence,

$\mathrm{T}_{1}$ - Control, $\mathrm{T}_{2}$ - Nipping $5 \mathrm{~cm}$ from growing tip, $\mathrm{T}_{3}$ - Nipping $8 \mathrm{~cm}$ from growing tip, $\mathrm{T}_{4}$ - Nipping $10 \mathrm{~cm}$ from growing tip, MBCR=Marginal benefit cost ratio

Input price: (Tk./ kg) Urea- $16^{-1}$, TSP-22 ${ }^{1}$, MoP-15 ${ }^{1}$, Gypsum-06, Power tiller (1 pass): Tk. ha ${ }^{-1} 2250{ }^{1}$, irrigation Tk. $\mathrm{kg}^{-1}$ (1 time): 900, labor: Tk. Day ${ }^{-1} 40008$ hours $^{-1}$, Tk. kg- chickpea seed-120 ${ }^{1}$

Output price: Tk. / kg : Chickpea- $70^{1}$, Vegetable-55

\section{Conclusion}

From the above findings, it can be concluded that growth and yield of chickpea is affected by detopping practice. Seed yield was maximum when chickpea plant (var. BARI Chola-10) is de-topped after 50 DAE (Days After Emergence) at $5 \mathrm{~cm}$ from growing tip followed by highest marginal benefit cost ratio. 


\section{References}

Aslam, M., A.H. Khalil, K. Himayatullah, M. Ayaz, M. Ejaz and M. Arshad. 2008. Effect of available soil moisture depletion levels and topping treatments on growth rate and total dry biomass in chickpea. J. Agri. Res. 46(3): 229-243.

Aslam, M., E.A. Khan, Himayatullah, M. Ayaz, H.K. Ahmad, M. Mansoor and K. Hussain. 2010. Effect of soil moisture depletions and de-topping on yield and yield components of chickpea. J. Agri. Res. 26(2): 177-186.

Azad, A.K., A. Wahab, M.G. Saha, Z. Nesa, M.L. Rahman, H.H. Rahman and L. Amin. 2019. Krishi Projukti Hatboi (Handbook on Agro-technology), 8th edition. Bangladesh Agricultural Research Institute, Gazipur-1701, Bangladesh: 47, 64, 67.

Aziz, M.A. 2000. Response of chickpea to nipping. Pakistan J. Sci. Indus. Res. 43(3): 191-192.

BBS (Bangladesh Bureua of Statistics). 2019. Yearbook of Agricultural Statistics-2018, p.08.

Campbell, N.A., J.B. Reece, L.A. Urry, M.L. Cain, S.A. Wasserman, P.V. Minorsky and R.B Jackson. 2008. Biology (8th ed.) Pearson Benjamin Cumming. San Francisco and London: pp.827-830.

Even, E.J. and A.G Wahab. 1983. Effect of leaf removal on the growth of winter oil seed rape (Brassica napus L.). Proc. 6th Int'l. Rapeseed Cong. Paris. 17-19 May, 1: 104-109.

Gaudreau, S., T. Missihoun and H. Germain. 2020. Early topping: an alternative to standard topping increases yield in cannabis production. Plant Sci. Today. 7(4): 627-630. https://doi.org/10.14719/pst.2020.7.4.927.

Khan, R.U., H.H. Muendel and M.F. Chaudhry. 1993. Effect of topping and ratooning on seed yield and fodder production of rape seed (Brassica napus L.). Agron. Trend Agric. Sci. 1: 17-23.

Kobir, M.S., M.H. Rashid and S. Ahmed. 2020. Development of integrated fertilizer management strategies in lentil for higher productivity in the South-Western region of Bangladesh. Agril. Sci. 2(1): 275281.https://doi.org/10.30560/as.v2n1p275.

Merga, B. and J. Haji. 2019. Economic importance of chickpea: Production, value, and world trade, Cogent Food \& Agriculture. 5 (1): 161. https://doi.org/10.1080/23311932.2019.1615718.

Othman, M. and Wan. 1987. The effects of height and frequency of previous defoliation on nodulation, nitrogen fixation and regrowth of Phasey bean AGRIS record FAO of the United Nations. 10(1): 110.

Sumarjit, S.M. and D.K. Sophia. 2006. Profitability of nipping in Pea (Pisum sativum L.) an indigenous agro-technique in Manipur. Indian. J. Agron. 51: 206-208.

Zahid, M.S., M.U. Mufti, S. Khan and M.B. Bhatti. 1997. Impact of improved varieties and production technology in improving the existing fodder production systems under the medium rainfall areas of Fatehjang (Attock district). Sarhad J. Agric. 13: 517-525. 